\title{
Hydrogeological and geochemical comparison of high and low arsenic groundwaters in the Hetao Basin, Inner Mongolia
}

\author{
H.Y. Wang \\ Institute of Mineralogy and Geochemistry, Karlsruhe Institute of Technology, Karlsruhe, Germany
}

\begin{abstract}
For deeply understanding the arsenic mobilization mechanisms of groundwater in Hetao Basin of Inner Mongolia, sediments and groundwater samples from two multi-level wells (up to $80 \mathrm{~m}$ ) were analyzed. The results showed that the sediment As content from well with high As concentration (K1) is higher than the well with low As concentration groundwater (K2), with the average As concentrations 14.7 and $12.8 \mathrm{mg} \mathrm{kg}^{-1}$ respectively. Interestingly, we found a gray-black peat layer (around $28 \mathrm{~m}$ ) from the $\mathrm{K} 2$, with arsenic concentration $322 \mathrm{mg} \mathrm{kg}^{-1}$, while the TOC content and TS contents are up to $9.6 \%$ and $1.8 \%$, respectively. The pyrite also was found in this layer. We conclude that the organic matter triggers the formation of arsenic-sequestering sulphides under strongly reducing conditions, therefore immobilization of As into the sediments. By bonding arsenic in this way, the peat layer occurred in the aquifer plays an active role for arsenic immobilization into the sediments.
\end{abstract}

\section{INTRODUCTION}

The Hetao Basin in the Inner Mongolia is one of most serious As-polluted area in China (Guo et al., 2014; Liu et al., 2017). Groundwater with high As concentration (up to $879 \mu \mathrm{g} \mathrm{L}^{-1}$ ) has been widely found in the Hetao Basin, with 76000 people exposed in 35 villages in 2002 (Liu et al., 2017).

For better understanding the mechanisms of As mobilization, we drilled two boleholes up to $80 \mathrm{~m}$ in Hangjinhoujin, one countryside highly affected by As pollution. The sediments from different layers were analyzed based on mineralogy and chemistry characters. And the relevance was established between the sediments property and groundwater As concentration.

\section{METHODS}

\subsection{Study area}

The Hetao Basin is located in between Yellow river to the south and Langshan to the north. Lacustrine deposition and frequent channel changes caused the patchy sediments distribution and allowed organic matter to accumulate in the sediments during Pleistocene and Holocene period. Hanginhouqi country located in the west of Hetao basin is one of the serious arsenicaffected areas where the groundwater was mainly used for irrigation system.

\subsection{Sediments characterization}

Two boreholes up to $80 \mathrm{~m}$ were drilled at the Hangjinhouqi in October of 2015. The XRF analysis was used to determine the mineral phases and major chemical components. The total carbon components (TC) and
TS as well as organic matter (TOC) were qualified using carbon-water analyzer. The EC (electric conductivity) value of soluble contents and $\mathrm{pH}$ values of sediments were also measured by method of solid-toliquid ratio of 1:5.

\subsection{Groundwater sampling and analysis}

After sediment sampling, the multi-level wells were installed. The water was pumped from the different depth. Groundwater parameters including temperature (T), $\mathrm{pH}$, redox potential (ORP), electrical conductivity (EC) were measured in the field. The major cations including As and anions were measured by ICP-MS and ICP-OES respectively.

\section{RESULTS AND DISCUSSION}

\subsection{Sediment geochemistry}

The average sediment grain sizes from K2 borehole are larger than $\mathrm{K} 1$, while the medium-coarse sands distribute in 35-40 $\mathrm{m}$ and 51-60 $\mathrm{m}$ from K2 borehole, they are rarely found in $\mathrm{K} 1$. Compared with $\mathrm{K} 1$, clay layers are also widely distributed in $\mathrm{K} 2$ with yellowbrown layers found in the depth around $16 \mathrm{~m}, 26 \mathrm{~m}$, $41 \mathrm{~m}, 51 \mathrm{~m}, 59 \mathrm{~m}, 65 \mathrm{~m}$ respectively, while only two clay layers appeared in $\mathrm{K} 1$ with the depth around $3 \mathrm{~m}$ above the aquifer, and $40 \mathrm{~m}$, respectively.

The sediment As contents ranged from 5.8 to $28.9 \mathrm{mg} \mathrm{kg}^{-1}$ (Table 1) with higher As contents of clay samples. Therefore, the clay layers intersected in the aquifers can be a major As sink or source. The As contents are well correlated with $\mathrm{Fe}$ contents in the sediments, rather than TOC and TS. So the As occurred in the aquifer are mostly from the 
Table 1. Chemical compositions of sediment samples collected from two boreholes in the western Hetao basin a: K1, b: $\mathrm{K} 2$ (except one sample with As content up to $322 \mathrm{mg} \mathrm{kg}^{-1}$ ). $\mathrm{a}:$

\begin{tabular}{lllllll}
\hline $\begin{array}{l}\text { Value } \\
\text { range }\end{array}$ & $\begin{array}{l}\mathrm{Fe}_{2} \mathrm{O}_{3} \\
(\mathrm{wt} \%)\end{array}$ & $\begin{array}{l}\mathrm{MnO} \\
(\mathrm{wt} \%)\end{array}$ & $\begin{array}{l}\mathrm{As} \\
\left(\mathrm{mg} \mathrm{kg}^{-1}\right)\end{array}$ & $\begin{array}{l}\mathrm{TOC} \\
(\%)\end{array}$ & $\begin{array}{l}\mathrm{TIC} \\
(\%)\end{array}$ & $\begin{array}{l}\mathrm{TS} \\
\left(\mathrm{mg} \mathrm{kg}^{-1}\right)\end{array}$ \\
\hline Maximum & 7.15 & 0.120 & 40.9 & 0.60 & 2.15 & 5125 \\
$75 \% \mathrm{Q}$ & 5.76 & 0.092 & 21.0 & 0.37 & 1.64 & 512 \\
Median & 3.39 & 0.047 & 12.1 & 0.13 & 0.97 & 287 \\
$25 \% \mathrm{Q}$ & 2.14 & 0.034 & 7.71 & 0.06 & 0.63 & 231 \\
Minimum & 1.61 & 0.023 & 5.82 & 0.04 & 0.32 & 140 \\
Average & 3.80 & 0.060 & 14.7 & 0.20 & 1.14 & 573 \\
$\mathrm{R}_{\mathrm{Fe}}^{2}$ & - & 0.93 & 0.75 & 0.61 & 0.80 & 0.0052 \\
$\mathrm{R}_{\mathrm{As}}^{2}$ & - & 0.61 & - & 0.35 & 0.40 & 0.0375 \\
\hline
\end{tabular}

b:

\begin{tabular}{llllllll}
\hline Maximum & 6.85 & 0.109 & 28.9 & 0.90 & 1.92 & 5438 \\
$75 \% \mathrm{Q}$ & 5.17 & 0.083 & 16.1 & & 0.47 & 1.74 & 685 \\
Median & 3.59 & 0.056 & 11.9 & 0.20 & 1.16 & 322 \\
$25 \% \mathrm{Q}$ & 2.16 & 0.029 & 6.59 & 0.06 & 0.53 & 226 \\
Minimum & 1.68 & 0.025 & 5.03 & 0.05 & 0.31 & 179 \\
Average & 3.69 & 0.058 & 12.8 & 0.2 & 1.10 & 724 \\
$\mathrm{R}_{\mathrm{Fe}}^{2}$ & - & 0.97 & 0.74 & 0.48 & 0.7 & 0.16 \\
$\mathrm{R}_{\mathrm{As}}^{2}$ & - & 0.66 & - & 0.50 & 0.6 & 0.35 \\
\hline
\end{tabular}

dissolution of $\mathrm{Fe} / \mathrm{Mn}$ (hydro) oxides or the $\mathrm{Fe}(\mathrm{Mn})$ oxides-TOC-As complexes.

The average As content $\left(14.7 \mathrm{mg} \mathrm{kg}^{-1}\right)$ in the $\mathrm{K} 1$ borehole is higher than in the $\mathrm{K} 2\left(12.7 \mathrm{mg} \mathrm{kg}^{-1}\right)$ (Table 1). It may be an important reason for higher groundwater As concentration from K1 well.

Interestingly, we found a gray-black peat layer in the $\mathrm{K} 2$ borehole, The deep sand layer contains trees and plants debris extending from 25.8 to $28.4 \mathrm{~m}$ with the As and TOC contents up to $322 \mathrm{mg} \mathrm{kg}^{-1}$ and $9.6 \%$ respectively. XRD spectra was used to investigate the mineral compositions, revealing that the pyrite minerals appeared in this layer. Under reducing conditions, the S-enriched peat can implicate as a fuel for reductive dissolution of arsenic-bearing iron (hydro) oxides, then accelerate the formation of arsenic-contained pyrite as a result of sufides reacting with the Fe (II).

\subsection{Soluble salts in the sediments}

Generally, the clay and silt samples exhibited higher salinity than the sand. However, the sand layers in the depth of around $80 \mathrm{~m}$ in $\mathrm{K} 1,28 \mathrm{~m}$ and $69 \mathrm{~m}$ in $\mathrm{K} 2$ released high contents of salts due to the high TOC contents (Fig. 1a). The sample EC values near the land surface from $\mathrm{K} 1$ are much higher than from $\mathrm{K} 2$, indicating that the groundwater from K1 well experienced long time evaporation and caused the salts accumulation in the surface sediments. Contrasting with K1, the sediments from K2 experienced long-term flushing history with low $\mathrm{EC}$ values appearing at different aquifer sediments.

Compared with higher sediment As concentration from $\mathrm{K} 1$ borehole, the sediments from $\mathrm{K} 2$ have higher $\mathrm{pH}$ value (Fig. 1a). It may be due to that at alkaline

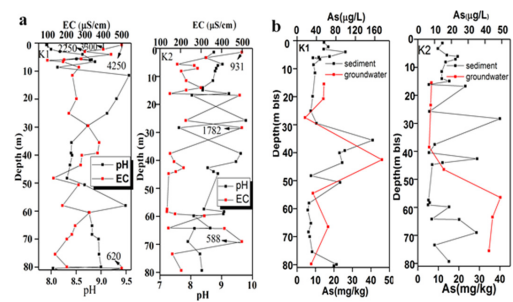

Figure 1. (a) EC value and $\mathrm{pH}$ of sediments varies with depth, (b) As concentrations of groundwater and sediments varies with dept.

conditions, dissolved Fe concentrations did not significantly increase upon reduction. Furthermore, the presence of soluble organics under alkaline conditions and the formation of iron oxyhydroxides-organic matter complexes could have retarded Fe reduction and the release of As into solution.

\subsection{Hydrogeochemistry}

The groundwater from $\mathrm{K} 2$ well showed higher $\mathrm{pH}$, consisting with higher $\mathrm{pH}$ in the sediments. The total dissolved solids (TDS) range from 449 to $3136 \mathrm{mg} \mathrm{L}^{-1}$, and decline with the depth. The groundwater from $\mathrm{K} 1$ well experienced long-time water-rock interaction or evaporation process with higher EC value. The groundwater samples from $\mathrm{K} 1$ well are mostly $\mathrm{Na}-\mathrm{Cl}-$ $\mathrm{SO}_{4}$ or $\mathrm{Na}_{-} \mathrm{SO}_{4}-\mathrm{Cl}$ type, while samples from $\mathrm{K} 2$ well are mostly $\mathrm{Na}(\mathrm{Ca})-\mathrm{HCO}_{3}-\mathrm{SO}_{4}$ type.

The ORP values of both wells are similar under anoxic conditions except the depth of $15-16 \mathrm{~m}$ in K2 well. The groundwater As concentrations from different depths of K2 well are lower than $50 \mu \mathrm{g} \mathrm{L}^{-1}$, and increased with depth (Fig. 1b). Even though the sediment As content in the depth of $28 \mathrm{~m}$ from K2 borehole is up to $322 \mathrm{mg} \mathrm{L}^{-1}$, the As concentration in the groundwater according to this depth is lower than $10 \mu \mathrm{g} \mathrm{L}^{-1}$. Therefore, we conclude that the peat layers accelerate the As immobilization into the sediments.

The groundwater As concentrations in K1 vary with the sediment As contents. The As concentration in the depth of $42.5 \mathrm{~m}$ is $174 \mu \mathrm{g} \mathrm{L}^{-1}$ while the As content in the upper clay sediment is up to $25 \mathrm{mg} \mathrm{kg}^{-1}$ (Fig. 1b). Under reducing conditions, the DOC released from clay layers above this aquifer may afford the electrons for release of $\mathrm{Fe}$ (hydro) oxides.

\section{REFERENCES}

Guo, H.M., Wen, D.G., Liu, Z.Y., Jia, Y.F. \& Guo, Q. 2014. A review of high arsenic groundwater in mainland and Taiwan, China: distribution, characteristics and geochemical processes. Appl. Geochem. 41: 196-217.

Liu, N.J., Deng, Y.M. \& Wang, Y. 2017. Arsenic, iron and organic matter in quaternary aquifer sediments from western Hetao Basin, Inner Mongolia. J. Earth Sci. 28: 473-483. 